\title{
Micro-flow in vivo Analysis of L-Glutamate with an On-line Enzyme Amplifier Based on Substrate Recycling
}

\author{
Toshio YAO, ${ }^{* \dagger}$ Youko NANJYO*, and Hirohito NiSHINO** \\ *Department of Applied Chemistry, Graduate School of Engineering, Osaka Prefecture University, \\ 1-1 Gakuencho, Sakai, Osaka 599-8531, Japan \\ **Eicom Ltd., 24-2 Shimotoba-Enmendacho, Fushimi, Kyoto 612-8474, Japan
}

\begin{abstract}
A micro-flow enzyme system with a microdialysis probe is proposed for the amperometric detection of trace amounts of neurotransmitter L-glutamate released from rat brain cells. The L-glutamate oxidase (EC 1.4.3.11)/glutamate dehydrogenase (EC 1.4.1.4) coimmobilized reactor was used to enhance the sensitivity of L-glutamate as an on-line amplifier based on substrate recycling. A poly(1,2-diaminobenzene) film-coated platinum electrode was also used to selectively detect only the hydrogen peroxide generated into a upstream enzyme reactor, without interference from oxidizable species, such as L-ascorbate, the adsorption of low molecular-weight proteins in a dialysate, and NADPH added to the carrier solution to initiate substrate recycling. By the present in vivo system, L-glutamate was selectively assayed with about a 600 -fold increase in sensitivity compared with the unamplified responses. The detection limit was $0.08 \mu \mathrm{mol} \mathrm{dm}{ }^{-3}$. This method was applied to an in vivo assay of L-glutamate in the extracellular space of rat brain; also, monitoring of the L-glutamate level changed after a continuous stimulation of $\mathrm{KCl}$ to demonstrate the reliability of the system.
\end{abstract}

(Received January 24, 2001; Accepted March 9, 2001)

The in vivo monitoring of concentration changes in transmitters that take place rapidly in brain cells has been especially desired in the research field of brain chemistry. L-Glutamate is one of the most important excitatory neurotransmitters in the brain..$^{1,2}$ Some enzyme-based amperometric biosensors ${ }^{3-7}$ have been proposed for the in vivo monitoring of the release of endogeneous glutamate into the extracellular space of the central nervous system. The use of these miniaturized biosensors was a marvelous approach for the in vivo monitoring of L-glutamate, but was limited because of variations in the sensitivity caused by the adsorption of proteins during prolonged in vivo monitoring.

In recent years, sensor systems that combine on-line microdialysis sampling have been developed for in vivo analysis and continuous monitoring. We reported before on a continuous-flow system $^{8}$ which makes possible the on-line monitoring of glucose, L-glutamate, and acetylcholine. This method is based on the use of a microdialysis probe in combination with an immobilized enzyme reactor. A similar attempt was achieved for the on-time monitoring of glucose $\mathrm{e}^{9,10}$ and L-glutamate ${ }^{11-13}$ by using a miniaturized enzyme electrode. However, the concentration of L-glutamate in the extracellular spaces of rat brain was normally at the few $\mu \mathrm{mol} \mathrm{dm}{ }^{-3}$ level, ${ }^{14,15}$ and the permeability of L-glutamate into the microdialysis probe was about $10 \%$ at a flow rate of $2 \mu \mathrm{min}^{-1}$ when Ringer's solution was pumped as a perfusion solution into the probe. As a result, a detection system with a detection limit less than $1 \times$ $10^{-7} \mathrm{~mol} \mathrm{dm}^{-3}$ was required for the in vivo monitoring of $\mathrm{L}-$ glutamate in the extracellular space of rat brain.

Consequently, an attempt was made to enhance the sensitivity

† To whom correspondence should be addressed. of the micro-flow system with an enzyme reactor based on the use of an enzyme reactor involving amplification by substrate recycling. This paper describes a micro-flow analytical system with a glutamate oxidase (GlOD)/glutamate dehydrogenase (GlDH) coimmobilized reactor which permitted selective detection with the amplification of L-glutamate. Two enzyme reactors prepared by coimmobilizing GIDHs from different sources [beef liver (EC 1.4.1.3) and Proteus sp. (EC 1.4.1.4)] and GlOD from Streptomyces sp. (EC 1.4.3.11) were compared concerning the amplification of L-glutamate detection. However, these commercially available enzymes contained a trace of $\mathrm{H}_{2} \mathrm{O}_{2}$-producing enzyme and glutaminase. Therefore, a few pretreatment procedures were required to improve the substrate specificity of the enzyme reactor. In addition, a poly(1,2-diaminobenzene) film-coated platinum electrode was also used for the highly selective detection of hydrogen peroxide generated enzymatically as an end product, without any electrochemical interference from $\mathrm{NAD}(\mathrm{P}) \mathrm{H}$ added to cause effective substrate recycling. As a result, this micro-flow system with microdialysis sampling permitted in vivo monitoring of the L-glutamate concentration change in rat brain.

\section{Experimental}

\section{Materials}

GIDHs (EC 1.4.1.3, $83 \mathrm{U} \mathrm{mg}^{-1}$ of protein from beef liver and EC 1.4.1.4, $300 \mathrm{U} \mathrm{mg}^{-1}$ from Proteus sp.) were obtained from Oriental Yeast (Tokyo) and Toyobo (Osaka), respectively. GIOD (EC 1.4.3.11, 22.4 U mg-1 of protein from Streptomyces sp.) was obtained from Yamasa Shoyu (Chiba). NAD coenzymes (NAD ${ }^{+}$: oxidized form; NADH: reduced form) and 
NADP coenzymes (NADP+: oxidized form; NADPH: reduced form) were obtained from Oriental Yeast (Tokyo) and saccharopine dehydrogenase (SDH: EC 1.5.1.7, $50 \mathrm{U} \mathrm{mg}^{-1}$ of protein from baker's yeast) and 6-diazo-5-oxo-L-norleucine (DON) were from Sigma (St. Louis, MO). L-Glutamic acid, 2oxoglutarate, sodium azide, 1,2-diaminobenzene, L-lysine, and glutaraldehyde were obtained from Wako (Osaka). These chemicals, except for GlOD, were used as received. All other chemicals were of analytical reagent grade. Distilled water purified using a Millipore Mill-Q system (Nippon Millipore Ltd., Tokyo) was used throughout. Controlled pore glass (aminopropyl CPG; mean pore size, $546 \AA$ A; particle size 200 400 mesh; amine content $52.9 \mu \mathrm{mol} \mathrm{g}{ }^{-1}$ ) was obtained from CPG Inc. (Fairfield, NJ), and was used as a support material for enzyme immobilization. The phosphate buffers used as a carrier solution were prepared from ammonium dihydrogenphosphate. The saline-phosphate buffer used as a perfusion medium was prepared from $\mathrm{NaCl}\left(137 \mathrm{mmol} \mathrm{dm}^{-3}\right)$, $\mathrm{KCl}\left(2.7 \mathrm{mmol} \mathrm{dm}^{-3}\right)$, sodium dihydrogenphosphate $(9.7 \mathrm{mmol}$ $\left.\mathrm{dm}^{-3}\right)$ and potassium dihydrogenphosphate $\left(1.5 \mathrm{mmol} \mathrm{dm}^{-3}\right)$ and adjusted to $\mathrm{pH} 7.4$.

\section{Preparation of immobilized reactors}

Before immobilization, GlOD was pretreated with $\mathrm{HCl}$ as follows: to inactivate a trace of $\mathrm{H}_{2} \mathrm{O}_{2}$-producing enzyme (probably NADH oxidase) contained as impurity in the Yamasa's enzyme reagent. An aqueous solution $(350 \mu \mathrm{l})$ containing GlOD (0.5 mg protein; $11.2 \mathrm{U}$ ) was adjusted to $\mathrm{pH} 3$ with $0.02 \mathrm{M} \mathrm{HCl}$, and allowed to stand for $30 \mathrm{~min}$. By this procedure, the impurity enzyme was inactivated without decreasing the GIOD activity. To this enzyme solution, a $1 \mathrm{~m}$ $\mathrm{dm}^{-3}$ aliquot of a sodium phosphate buffer (0.2 M, pH 7.0) was added to adjust to $c a$. $\mathrm{pH} 7$. Furthermore, $1.5 \mathrm{mg}$ each of GIDHs (125 U for EC 1.4.1.3 enzyme and $450 \mathrm{U}$ for EC 1.4.1.4 enzyme) was added to separately pretreated GIOD solutions, and used for the immobilization. Then, a $8.5-\mathrm{mg}$ volume of aminopropyl CPG was packed into a PTFE tube $(10 \mathrm{~mm} \times 1.5$ $\mathrm{mm}$ i.d.) furnished with a small nylon net (350 mesh) at each end, and activated by a glutaraldehyde treatment, as previously described. $^{8}$ Two mixed solutions of GIOD and GIDH from different sources were circulated through two separately activated CPG reactors, respectively. By this immobilization procedure, two enzyme reactors (GlOD/GIDH (1.4.1.3) and GlOD/GIDH (1.4.1.4) coimmobilized reactors) were prepared. Furthermore, the trace amounts of glutaminase in the prepared enzyme reactors were inactivated by pumping $2 \mathrm{mmol} \mathrm{dm}^{-3}$ DON-0.1 mol dm ${ }^{-3}$ phosphate buffer ( $\left.\mathrm{pH} 7.0\right)$ into each reactor

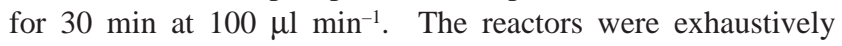
washed with the same phosphate buffer. Similarly, the GlOD reactor and the SDH reactor were prepared by immobilizing 11.2 U GIOD and 50 U SDH, respectively, onto saparate CPGpacked reactors according to the same procedures. These reactors were stored at $5^{\circ} \mathrm{C}$ in a $0.1 \mathrm{~mol} \mathrm{dm}^{-3}$ sodium phosphate buffer ( $\mathrm{pH} 7.0)$ when not in use.

Preparation of a poly(1,2-diaminobenzene) film-coated platinum electrode

The poly(1,2-diaminobenzene) film-coated platinum electrode was used as an amperometric detector of hydrogen peroxide generated enzymatically in the GlOD/GlDH coimmobilized reactors. This was prepared by a surface modification of the Eicom (Kyoto) thin-layer electrochemical flow-cell. Prior to coating, the surface of the platinum disk $(\phi 3 \mathrm{~mm})$ was polished with $1 \mu \mathrm{m}$ diamond particles (BAS, code no. 11-2054), and then washed with distilled water. The electropolymerization to coat
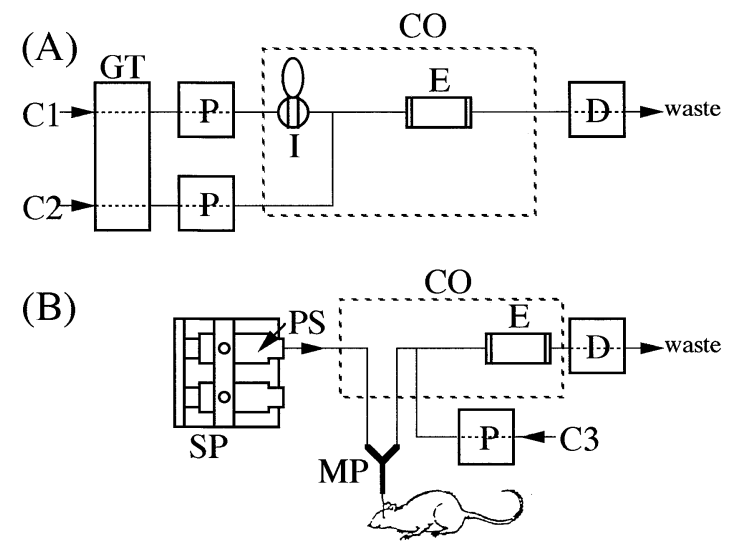

Fig. 1 (A) FIA manifold used to evaluate the characteristics of the enzyme reactor. (B) Micro-flow system used for an in vivo assay of L-glutamate. C1, Carrier buffer; $\mathrm{C} 2$ and C3, carrier buffer containing NADH or NADPH; PS, perfusion solution (saline-phosphate buffer); $\mathrm{D}$, poly(1,2-diaminobenzene) film-coated platinum electrode $\left(E_{\text {app }}=\right.$ $0.5 \mathrm{~V}$ vs. $\mathrm{Ag} / \mathrm{AgCl}$ ); E, L-glutamate oxidase/glutamate dehydrogenase coimmobilized reactor; MP, microdialysis probe; GT, gastorr; P, double-plunger $\mu$ l pump; SP, microsyringe pump; CO, thermostated column oven; I, injector with a sample loop of $25 \mu$ l.

the same surface with a thin film of poly(1,2-diaminobenzene) was carried according to procedures described before. ${ }^{16}$

\section{Apparatus and procedures}

The FIA system shown in Fig. 1A was used to optimize the parameters which influence the enzymatic behavior, by positioning the enzyme reactor. The FIA set up was made up of an Eicom GASTORR, two double-plunger $\mu$ l pumps (Eicom), an injector (Rheodyne 7725) with a PTFE sample loop of $25 \mu \mathrm{l}$, an electrochemical detector (Eicom ECD-300) with a potentiostat and a flow-cell, a thermostated column oven (Shimazu CTO-10A) and an SIC Chromatocorder. A constant potential $(+0.5 \mathrm{~V} v s . \mathrm{Ag} / \mathrm{AgCl})$ was applied to the polymer filmcoated platinum electrode and the current was recorded. Carrier solutions optimized for the use of the enzyme reactor were 0.1 mol dm $\mathrm{dm}^{-3}$ ammonium phosphate buffer for carrier $\mathrm{C} 1$ and the same phosphate buffer containing NADH or NADPH for carrier C2. Both buffers were pumped at the same flow-rates with double-plunger $\mu$ l pumps.

The microdialysis continuous flow-system used in this work is also outlined in Fig. 1B. The flow-through microdialysis probe was a gift from Eicom (BDP-I-8-03). The design was almost identical to that described before. ${ }^{8}$ The saline-phosphate buffer was pumped at a constant flow $\left(2 \mu \mathrm{min}^{-1}\right)$ into the dialysis probe with a microsyringe pump (Eicom EP-60). Ammonium phosphate buffer $\left(0.1 \mathrm{~mol} \mathrm{dm}^{-3}, \mathrm{pH} 7.5\right)$ containing $0.3 \mathrm{mmol}$ $\mathrm{dm}^{-3}$ NADPH was also pumped at $8 \mu \mathrm{min}^{-1}$ with a doubleplunger $\mu$ l pump. The L-glutamate in dialysate from the probe was amplified to a large amount of hydrogen peroxide by substrate recycling into the reactor, which could be detected amperometrically at a downstream poly(1,2-diaminobenzene) film-coated platinum electrode. The steady-state current was recorded by a SECONIC SS-250F strip chart recorder. All of the parts were connected with PTFE coils $(0.125 \mathrm{~mm}$ i.d., $20 \mathrm{~cm}$ length) for both systems. As a result, the inner volume of the flow line between the output of a microdialysis probe and a detector (Fig. 1B) was limited to $c a .8 .8 \mu \mathrm{l}$, except for the dead volume of the reactor. 
Table 1 Background current caused by the presence of $0.75 \mathrm{mmol} \mathrm{dm}^{-3}$ NADPH and NADH in the carrier buffer ${ }^{\mathrm{a}}$ and the effect of acidic pretreatment of the GIOD before immobilization

\begin{tabular}{|c|c|c|c|c|c|c|}
\hline \multirow{3}{*}{$\begin{array}{c}\text { Total carrier } \\
\text { flow rate/ } \\
\mu 1 \mathrm{~min}^{-1}\end{array}$} & \multicolumn{6}{|c|}{ Background current/nA } \\
\hline & \multicolumn{3}{|c|}{ in the presence of NADPH } & \multicolumn{3}{|c|}{ in the presence of NADH } \\
\hline & without reactor & $\mathrm{GlOD}^{\mathrm{b}}$ & $\mathrm{GlOD} / \mathrm{GlDH}^{\mathrm{c}}$ & without reactor & $\mathrm{GlOD}^{\mathrm{b}}$ & $\mathrm{GlOD} / \mathrm{GlDH}^{\mathrm{c}}$ \\
\hline 10 & 16 & $127(22)$ & $98(21)$ & 20 & $908(55)$ & 903(51) \\
\hline 40 & 14 & $61(19)$ & $45(18)$ & 18 & $900(34)$ & $730(28)$ \\
\hline 100 & 13 & $31(15)$ & $26(15)$ & 15 & $690(25)$ & $470(22)$ \\
\hline
\end{tabular}

a. $0.1 \mathrm{~mol} \mathrm{dm}^{-3}$ ammonium phosphate buffer ( $\left.\mathrm{pH} 7.5\right)$. b. L-Glutamate oxidase (GlOD) immobilized reactor. c. L-Glutamate oxidase (GlOD)/glutamate dehydrogenase (GIDH: EC 1.4.1.4, from Proteus sp.) coimmobilized reactor. The values in parentheses indicate background currents caused by enzyme reaction with GlOD pretreated for $30 \mathrm{~min}$ at $\mathrm{pH} 3$ with $0.02 \mathrm{~mol} \mathrm{dm}^{-3} \mathrm{HCl}$.

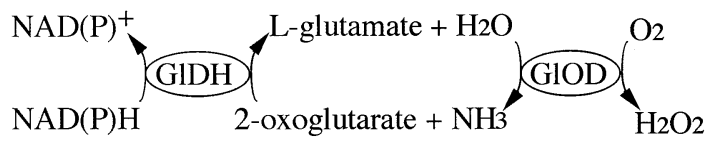

Fig. 2 Substrate recycling reaction of L-glutamate in the Lglutamate oxidase (GlOD)/glutamate dehydrogenase (GIDH) coimmobilized reactors.

\section{Results and Discussion}

Inactivation of impurity enzymes in L-glutamate oxidase

The GIOD/GIDH coimmobilized reactor was used as an online amplifier of L-glutamate based on substrate recycling. GIDHs from two sources, beef liver (EC 1.4.1.3) and proteus $s p$. (EC 1.4.1.4), exhibited a difference in the reaction specificity for the coenzymes; the EC 1.4.1.3 enzyme is not specific between the coenzymes (NADH and NADPH) and EC 1.4.1.4 enzyme is specific for NADPH. Two enzyme reactors were prepared by coimmobilizing GIOD and GlDHs from different sources. As can be seen from Fig. 2, an excess of $\mathrm{NADH}$ or NADPH has to be added to the carrier solution to cause effective recycling of L-glutamate.

A poly(1,2-diaminobenzene) film-coated platinum electrode was used to detect the hydrogen peroxide produced by enzymatic substrate recycling, without an increase in the baseline current, owing to the direct oxidation of NADH (or $\mathrm{NADPH}$, because the poly(1,2-diaminobenzene) film effectively prevented NADH (or NADPH) in the carrier stream from reaching the electrode surface, and allowed only the hydrogen peroxide to penetrate into the polymerized film, as described before. ${ }^{16}$ Actually, the poly(1,2-diaminobenzene) film-coated platinum electrode gave only a small base-line current, even in the presence of $0.75 \mathrm{mmol} \mathrm{dm}^{-3} \mathrm{NADH}$ (or $\mathrm{NADPH}$ ) in carrier $\mathrm{C} 2$ in the FIA system (Fig. 1A) without an enzyme reactor, e.g., $20 \mathrm{nA}$ or $16 \mathrm{nA}$ at a flow rate of $10 \mu \mathrm{l}$ $\mathrm{min}^{-1}$ (see Table 1). However, when the GlOD/GIDH (EC 1.4.1.4) coimmobilized reactor was incorporated in the FIA flow-line, a large background current was caused, as shown in Table 1, especially at low flow-rates and in the presence of NADH as a coenzyme. A similar result was also obtained for the GIOD immobilized reactor and for the GlOD/GIDH (EC 1.4.1.3) coimmobilized reactor, though not shown in Table 1. From these results, this large background current was probably considered to be caused by the trace amounts of an $\mathrm{H}_{2} \mathrm{O}_{2-}$ producing enzyme contained as an impurity in the commercially available GIOD. It may be a trace of NADH oxidase (probably not NADPH oxidase) which oxidizes NADH to $\mathrm{NAD}^{+}$to produce $\mathrm{H}_{2} \mathrm{O}_{2}$. Therefore, an acidic pretreatment of GlOD was examined to inactivate such an impurity enzyme, because it was known that GlOD was moderately stable in an acidic solution. According to the procedures described in Experimental section, the GlOD solution was pretreated for $30 \mathrm{~min}$ at $\mathrm{pH} 3$ with 0.02 mol dm ${ }^{-3} \mathrm{HCl}$, and was then used for the immobilization. This acidic pretreatment at $\mathrm{pH} 3$ tended to decrease the background current up to fairly small values (Table 1), while maintaining the GlOD activity constant. However, the pretreatment at $\mathrm{pH}$ values below 2.5 caused the GIOD activity to completely disappear. Such an acidic pretreatment was a simple and effective method to inactivate an $\mathrm{H}_{2} \mathrm{O}_{2}$-producing enzyme contained as an impurity in GIOD.

However, this reactor gave a response to glutamine at low flow rates. The response to $10 \mu \mathrm{mol} \mathrm{dm}{ }^{-3}$ glutamine was $75 \%$ of that to $10 \mu \mathrm{mol} \mathrm{dm}{ }^{-3} \mathrm{~L}$-glutamate at a total flow rate of $20 \mu \mathrm{l}$ $\mathrm{min}^{-1}$ in the FIA system shown in Fig. 1A. This is probably due to the presence of a trace amount of glutaminase contained as an impurity in GIOD and/or the GIDH used in this work. Glutaminase catalyzes a reaction of glutamine to L-glutamate according to

$$
\text { L-glutamine }+\mathrm{H}_{2} \mathrm{O} \longrightarrow \text { L-glutamate }+\mathrm{NH}_{4}{ }^{+} \text {. }
$$

The DON is $\operatorname{known}^{17,18}$ as an irreversible inhibitor of glutaminase. Therefore, a $0.1 \mathrm{~mol} \mathrm{dm}^{-3}$ phosphate buffer $(\mathrm{pH}$ 7.0) containing $2 \mathrm{mmol} \mathrm{dm}{ }^{-3}$ DON was pumped into the reactors for $30 \mathrm{~min}$ at a flow rate of $100 \mu \mathrm{lmin}^{-1}$. After this

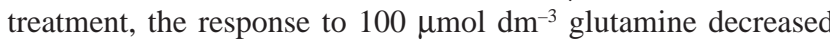

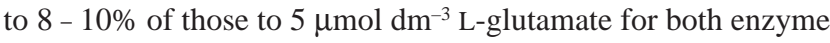
reactors, at a flow rate of $10 \mu 1 \mathrm{~min}^{-1}$.

\section{Characterization of enzyme reactors involving amplification}

Experiments were conducted to establish the optimum experimental conditions for amplification and to evaluate the differences between the two GlOD/GIDH coimmobilized reactors, using the FIA system shown in Fig. 1A. Table 2 shows the range over which each variable was studied and the optimal values found. Three types of buffer $\left(0.1 \mathrm{~mol} \mathrm{dm}^{-3}, \mathrm{pH} 7.0\right.$; ammonium phosphate, Tris- $\mathrm{HCl}$, and citrate) containing 0.5 mmol $\mathrm{dm}^{-3} \mathrm{NADPH}$, were tested as the carrier buffer. An excess of $\mathrm{NH}_{4} \mathrm{Cl}\left(50 \mathrm{mmol} \mathrm{dm}{ }^{-3}\right.$ each) was also added to Tris- $\mathrm{HCl}$ and citrate buffers to cause the effective recycling of L-glutamate. Three buffers were pumped at a total flow rate of 
Table 2 Optimization of the variables used in GlOD/GIDH coimmobilized reactors

\begin{tabular}{|c|c|c|c|c|}
\hline & \multirow{2}{*}{ Variable } & \multirow{2}{*}{ Range studied } & \multicolumn{2}{|c|}{ Enzyme reactor } \\
\hline & & & GlOD/GIDH (EC 1.4.1.3) & GlOD/GlDH (EC 1.4.1.4) \\
\hline \multirow[t]{4}{*}{ Chemical } & Buffer & Three kinds $^{\mathrm{c}}$ & $\begin{array}{l}\text { ammonium phosphate } \\
\quad\left(0.1 \mathrm{~mol} \mathrm{dm}^{-3}\right)\end{array}$ & $\begin{array}{l}\text { ammonium phosphate } \\
\qquad\left(0.1 \mathrm{~mol} \mathrm{dm}^{-3}\right)\end{array}$ \\
\hline & $\mathrm{pH}$ & $6.0-8.5$ & 6.5 & 7.5 \\
\hline & $\mathrm{NADH}\left(\mathrm{mmol} \mathrm{dm}^{-3}\right)$ & $0-1.5$ & 0.3 & - \\
\hline & NADPH $\left(\mathrm{mmol} \mathrm{dm}^{-3}\right)$ & $0-1.5$ & 0.3 & 0.3 \\
\hline \multirow[t]{2}{*}{ Physical } & Reactor temperature $\left({ }^{\circ} \mathrm{C}\right)$ & $27-45$ & 37 & 37 \\
\hline & Flow rate $\left(\mu 1 \min ^{-1}\right)$ & $5-60$ & \multicolumn{2}{|c|}{ The signal intensity increased with decreasing flow rate (see Fig. 3). } \\
\hline
\end{tabular}

a. L-Glutamate oxidase (GlOD)/glutamate dehydrogenase (GIDH: EC 1.4.1.3, from beef liver) coimmobilized reactor. b. L-Glutamate oxidase (GlOD)/glutamate dehydrogenase (GIDH: EC 1.4.1.4, from Proteus sp.) coimmobilized reactor. c. 0.1 mol dm ${ }^{-3}$ ammonium phosphate buffer and Tris- $\mathrm{HCl}$ and citrate buffers added $50 \mathrm{mmol} \mathrm{dm}^{-3} \mathrm{NH}_{4} \mathrm{Cl}$.

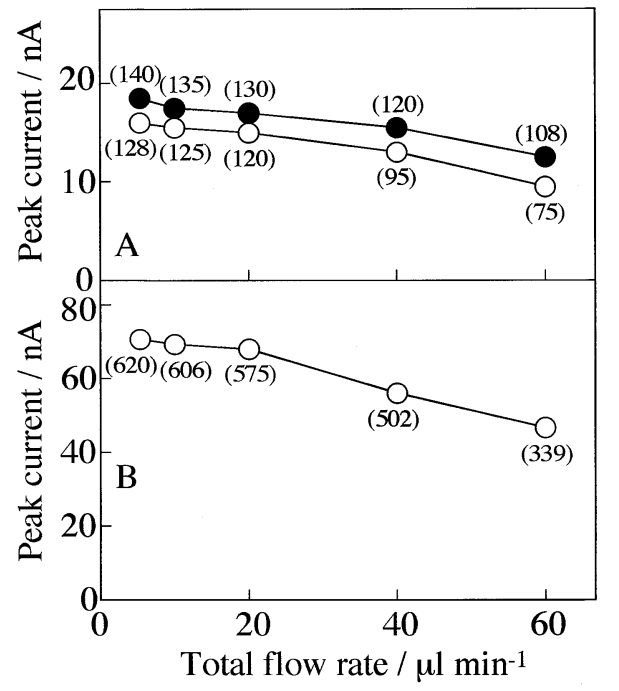

Fig. 3 Effect of the carrier flow rate on substrate amplification in the FIA system with the GlOD/GIDH (EC 1.4.1.3) reactor (A) and the GIOD/GIDH (EC 1.4.1.4) reactor (B): amplified response for a 10

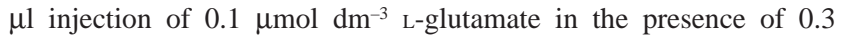
$\mathrm{mmol} \mathrm{dm}^{-3} \mathrm{NADPH}(\mathrm{o})$ and $0.3 \mathrm{mmol} \mathrm{dm}^{-3} \mathrm{NADH}(\bullet)$ in the carrier buffer. The experiment was performed by using the FIA system shown in Fig. 1A. The values in parentheses indicate the amplification factor at each flow rate.

$100 \mu 1 \mathrm{~min}^{-1}$ through the GlOD/GIDH coimmobilized reactors. An ammonium phosphate buffer was selected as the optimal carrier buffer, because it provided the greatest signal for the amplification of L-glutamate in both enzyme reactors; the signal current was approximately 3.2-times and 6.1-times those in the Tris- $\mathrm{HCl}$ and citrate buffers, respectively.

The effect of the $\mathrm{pH}$ of the carrier buffer was investigated next. The maximum response for L-glutamate was obtained at $\mathrm{pH} 6.5$ and 7.5 for the GlOD/GIDH (EC 1.4.1.3) and GIOD/GIDH (EC 1.4.1.4) coimmobilized reactors, respectively.

Without NADPH in the carrier buffer, only a small signal for L-glutamate was observed, with no signal for 2-oxoglutarate upon the use of both enzyme reactors. When the NADPH concentration was increased from 0 to $0.3 \mathrm{mmol} \mathrm{dm}^{-3}$, the sensitivity to L-glutamate was increased 119 times and 573 times, respectively, for the GlOD/GIDH (EC 1.4.1.3) and GlOD/GIDH (EC 1.4.1.4) reactors at a total flow rate of $20 \mu \mathrm{l}$ $\mathrm{min}^{-1}$. In contrast, the increase in the NADH concentration from 0 to $0.3 \mathrm{mmol} \mathrm{dm}^{-3}$ increased to 125 -times the sensitivity to L-glutamate for the GIOD/GIDH (EC 1.4.1.3) reactor, but did not increase for the GlOD/GIDH (EC 1.4.1.4) reactor. These results indicate that the recycling of L-glutamate occurs effectively between the coupled enzymes in the presence of NADPH because oxygen is dissolved in the carrier buffer. However, the increase was only slight at higher concentrations of NADPH, probably because of limited oxygen in the carrier solution. From these results, $0.3 \mathrm{mmol} \mathrm{dm}^{-3} \mathrm{NADPH}$ was added to the carrier buffer (carrier C2 in Fig. 1A and carrier C3 in Fig. 1B) as a coenzyme to cause the amplification of Lglutamate for both enzyme reactors.

The temperature of the enzyme reactors was increased by keeping them in a thermostated column oven. When the reactor temperature increased from 27 to $40^{\circ} \mathrm{C}$, the sensitivity to Lglutamate was increased by $c a$. 1.5 times for both reactors, becoming almost constant at $46^{\circ} \mathrm{C}$, and then gradually decreasing at higher temperatures.

Because the carrier flow rate is related to the residence time of the sample zone in the enzyme reactor (i.e. the turnover numbers of recycling), the signal intensity increased with decreasing carrier flow rate, as shown in Fig. 3. For the GlOD/GIDH (EC 1.4.1.3) reactor, both NADPH and NADH work likewise as a coenzyme to cause substrate recycling; however for the GIOD/GIDH (EC 1.4.1.4) reactor, only NADPH works effectively for substrate recycling.

\section{Optimization of the in vivo micro-flow system}

In this work, the GlOD/GIDH (EC 1.4.1.4) coimmobilized reactor was used to amplify L-glutamate, and was positioned in front of the flow cell (see Fig. 1B). Saline-phosphate buffer (perfusion solution) was pumped at $2 \mu \mathrm{l} \min ^{-1}$ with a microsyringe pump, because of a smaller fluctuation in the base-line current than using a double-plunger $\mu$ l pump. As an optimum carrier buffer (carrier C3 in Fig. 1B), $0.1 \mathrm{~mol} \mathrm{dm}^{-3}$ ammonium phosphate buffer at $\mathrm{pH} 7.5$ containing $0.3 \mathrm{mmol}$

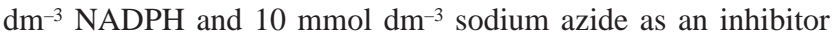
for catalase was selected and pumped at $5 \mu \mathrm{min}^{-1}$ with a double-plunger $\mu \mathrm{l}$ pump. The microdialysis probe was immersed in a saline-phosphate buffer containing $5 \mu \mathrm{mol} \mathrm{dm}{ }^{-3}$ L-glutamate, and a steady-state current was recorded. Also, the same L-glutamate solution was pumped directly into the enzyme reactor. From a comparison of these response currents, it was estimated that the peamiability of L-glutamate into the probe was $c a .13 .5 \%$. At higher flow rates of a perfusion solution, the 


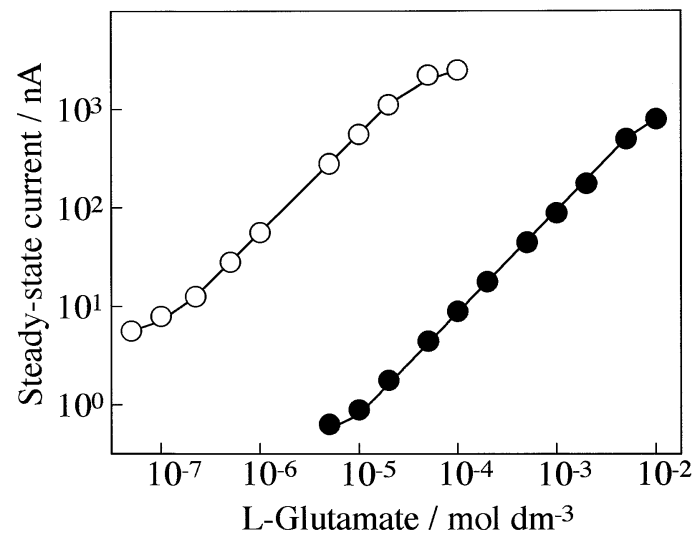

Fig. 4 Calibration graphs for L-glutamate obtained by a microdialysis micro-flow system. ( o ) Amplified signal obtained in the presence of NADPH; (•) no amplified signal obtained in the absence of NADPH. The carrier buffer $\left(0.1 \mathrm{~mol} \mathrm{dm}^{-3}\right.$ ammonium phosphate buffer, $\mathrm{pH} 7.5$ ) containing $0.3 \mathrm{mmol} \mathrm{dm}^{-3} \mathrm{NADPH}$ and 10 mmol $\mathrm{dm}^{-3}$ sodium azide and the saline-phosphate buffer were pumped at 8 and $2 \mu \mathrm{min}^{-1}$, respectively, in the micro-flow system shown in Fig. 1B. The microdialysis probe was immersed in a salinephosphate buffer containing different concentrations of L-glutamate, and the steady-state current was recorded.

permeability decreased, e.g., $8.7 \%$ and $6.5 \%$ at 3 and $4 \mu 1 \mathrm{~min}^{-1}$, respectively. Therefore, this flow rate was selected in this work.

When the flow rate of carrier buffer C3 was increased, keeping that of the perfusion solution constant $\left(2 \mu 1 \mathrm{~min}^{-1}\right)$, the response current was gradually decreased, because of dilution of the dialysate from a microdialysis probe and a decrease in the turnover numbers of substrate recycling. However, the time required to reach a steady-state response decreased as expected. From these results, the perfusion solution and carrier buffer $\mathrm{C} 3$ were pumped at flow rates of 2 and $8 \mu \mathrm{min}^{-1}$, respectively, because this provided good sensitivity for L-glutamate detection and a reasonable response time $(4.0 \mathrm{~min}$ for L-glutamate detection). Under the recommended flow conditions, a linear calibration plot for L-glutamate was obtained over the range of 2 $\times 10^{-7}-2 \times 10^{-5} \mathrm{~mol} \mathrm{dm}^{-3}$, as shown in Fig. 4. The detection limit was $0.8 \times 10^{-7} \mathrm{~mol} \mathrm{dm}^{-3}(S / N=3)$ and the relative standard deviation for five replicate measurements was $3.8 \%$ for $5 \mu \mathrm{mol}$ $\mathrm{dm}^{-3} \mathrm{~L}$-glutamate. Also, in the absence of NADPH in the buffer, the response with no amplification depended linearly on the L-glutamate concentration between $1 \times 10^{-5}$ and $5 \times 10^{-3} \mathrm{~mol}$ $\mathrm{dm}^{-3}$, and the detection limit was $0.8 \times 10^{-5} \mathrm{~mol} \mathrm{dm}^{-3}(\mathrm{~S} / \mathrm{N}=3)$. This result indicates that the GlOD/GIDH coimmobilized reactor is useful as an on-line amplifier to increase the sensitivity of L-glutamate detection in the microdialysis flowsysterm with an enzyme reactor.

In vivo measurement of $L$-glutamate released from rat brain cells

In vivo monitoring of L-glutamate in rat brain was conducted by using the system shown in Fig. 1B under the recommended flow conditions and implanting a microdialysis probe into the frontal lobe of rat brain. The rat was allowed to recover overnight in a large plastic box with free access to food and water. The probe was then connected to a microsyringe pump through a swivel to allow the rat free movement.

When ammonium phosphate buffer $\left(0.1 \mathrm{~mol} \mathrm{dm}^{-3}, \mathrm{pH} 7.5\right)$ containing $0.3 \mathrm{mmol} \mathrm{dm}{ }^{-3} \mathrm{NADPH}$ and $10 \mathrm{mmol} \mathrm{dm}{ }^{-3}$ sodium

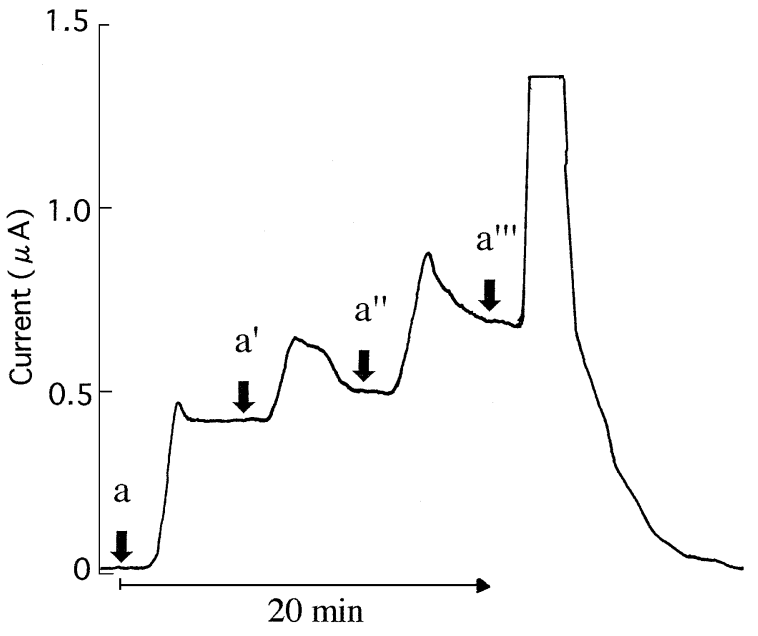

Fig. 5 Signal currents of L-glutamate released from rat brain cells by the $\mathrm{KCl}$ stimulation. The $\mathrm{KCl}$ concentration in saline-phosphate buffer: a, $2.7 \mathrm{mmol} \mathrm{dm} \mathrm{dm}^{-3}$; $\mathrm{a}^{\prime}, 10 \mathrm{mmol} \mathrm{dm}{ }^{-3}$; a", $20 \mathrm{mmol} \mathrm{dm}^{-3}$; a"', $100 \mathrm{mmol} \mathrm{dm}^{-3}$

azide was pumped at $8 \mu \mathrm{l} \mathrm{min}{ }^{-1}$, a constant base-line current was obtained. When a saline-phosphate buffer was then pumped at $2 \mu \mathrm{min}^{-1}$, the signal current increased up to a steady value after 4-5 min, corresponding to $5.8 \mu \mathrm{mol} \mathrm{dm}{ }^{-3} \mathrm{~L}$ glutamate content. Also, in the in vivo system without an enzyme reactor, the base-line current did not vary after the saline-phosphate buffer was pumped. This means that the poly(1,2-diaminobenzene) film-coated platinum electrode used as an $\mathrm{H}_{2} \mathrm{O}_{2}$ detector prevented the electroactive interferents (ascorbate etc.) from reaching the electrode surface and from interfering with the detection of hydrogen peroxide generated in the enzyme reactor.

However, it is anticipated that the presence of 2-oxoglutarate interferes with the measurement of L-glutamate, because substrate recycling is also initiated with 2-oxoglutarate (see Fig. 2). Because of this, the SDH immobilized reactor was inserted in series before the GIOD/GIDH (EC 1.4.1.3) coimmobilized reactor to remove 2-oxoglutarate in the dialysate according to

$$
\begin{aligned}
& \text { 2-oxoglutarate + L-lysine + NADH } \stackrel{\mathrm{SDH}}{\longrightarrow} \\
& \text { saccharopine }+\mathrm{NAD}^{+},
\end{aligned}
$$

and ammonium phosphate buffer $\left(0.1 \mathrm{~mol} \mathrm{dm}^{-3}, \mathrm{pH}\right.$ 6.7) containing $0.3 \mathrm{mmol} \mathrm{dm}{ }^{-3} \mathrm{NADH}$ and $5 \mathrm{mmol} \mathrm{dm}^{-3}$ L-lysine was pumped. However, the signal current was only little changed, in spite of being with and without the SDH immobilized reactor in the flow system. This means that the 2oxoglutarate content in dialysate is extremely less than that of Lglutamate in the extracellular space of rat brain. Therefore, the measurements were performed with the microdioalysis flow system without the SDH reactor and with the GIOD/GIDH (EC 1.4.1.4) reactor.

This method was also applied to the monitoring of the concentration change in the L-glutamate released from rat-brain cells as a result of $\mathrm{KCl}$ stimulation. Figure 5 also shows the increase in the L-glutamate concentration in rat brain when the $\mathrm{KCl}$ concentration in a saline-phosphate buffer used as a perfusion solution was increased from $2.7 \mathrm{mmol} \mathrm{dm}^{-3}$ up to 100 mmol dm${ }^{-3}$. This increase was due to continuous stimulation caused by $\mathrm{KCl}$ excluded from the dialysis probe into the extracellular space. However, the continuous stimulation of 100 
mmol $\mathrm{dm}^{-3} \mathrm{KCl}$ ultimately resulted in no signal after the appearance of a large signal caused by a large amount of Lglutamate released from some of the destroyed brain cells.

It was found from these results that the present microdialysis continuous flow-system is useful for the in vivo monitoring of trace amounts of L-glutamate released from rat-brain cells.

The two GlOD/GIDH coimmobilized reactors used in this work were used repeatedly; after repetitive use (about $4 \mathrm{~h}$ per day) for 30 days the sensitivity to L-glutamate decreased up to $76-84 \%$. Similarly, the poly(1,2-diaminobenzene) film-coated platinum electrode was stable enough to use for 20 days, but after that it gradually lost its desired properties.

\section{Acknowledgements}

The author (T. Y.) wishes to express his appreciation to the Ministry of Education, Science and Culture of Japan for Scientific Research for financial support (No. 11640612) of this research project.

\section{References}

1. C. E. Jahr and R. A. Lester, Curr. Opin. Neurobial., 1992, 2, 270 .

2. F. Dagani and E. D'Angelo, Funct. Neurol., 1992, 7, 315.

3. Y. Hu, K. M. Mitchell, F. N. Albahadily, E. K. Michaelis, and G. S. Wilson, Brain Res., 1994, 659, 117.
4. J. M. Cooper, P. L. Foreman, A. Glidle, T. W. Ling, and D. J. Pritchard, J. Electroanal. Chem., 1995, 388, 143.

5. W. G. Kuhr, V. L. Barrett, M. R. Gagnon, P. Hopper, and P. Pantano, Anal. Chem., 1993, 65, 617.

6. M. R. Ryan, J. P. Lowry, and R. D. O'Neill, Analyst, 1997 , $122,1419$.

7. S. Cosnier, C. Innocent, L. Allien, S. Poitry, and M. Tsacopoulos, Anal. Chem., 1997, 69, 968.

8. T. Yao, S. Suzuki, H. Nishino, and T. Nakahara, Electroanalysis, 1995, 7, 1114

9. D. Moscone, M. Pasini, and M. Mascini, Talanta, 1992, 39, 1039.

10. E. Zilkha, A. Koshy, T. P. Obrenovitch, H. P. Bennetto, and L. Symon, Anal. Lett., 1994, 27, 453.

11. O. Niwa, K. Torimitsu, M. Morita, P. Osborne, and K. Yamamoto, Anal. Chem., 1996, 68, 1865.

12. O. Niwa, T. Horiuchi, and K. Torimitsu, Biosensors Bioelectronics, 1997, 12, 311.

13. M. O. Berners, M. G. Boutelle, and M. Fillenz, Anal. Chem., 1994, 66, 2017.

14. A. S. Hazell, R. F. Butterworth, and A. M. Hakim, J. Neurochem., 1993, 61, 1153.

15. T. J. O'Shea, P. L. Weber, B. P. Bammel, C. E. Lunte, and M. R. Smyth, J. Chromatogr., 1992, 608, 189.

16. T. Yao, M. Satomura, and T. Nakahara, Electroanalysis, 1995, 7, 395.

17. S. C. Hartman, J. Biol. Chem., 1968, 243, 853.

18. J. S. Holcenberg, L. Ericsson, and J. Roberts, Biochemistry, 1978, 17, 411. 